\title{
EFFECT OF PENTACHLOROPHENOL ON SELECTED SOIL ENZYME ACTIVITIES IN A CHILEAN ANDISOL
}

\author{
M. Cristina Diez J. ${ }^{1}$, Felipe Gallardo A. ${ }^{2}$, Gissele Saavedra ${ }^{2}$, Mara Cea L. ${ }^{1}$ Liliana \\ Gianfreda $^{3}$, Marysol Alvear Z. ${ }^{2}$ \\ ${ }^{1}$ Depto Ingeniería Química, Universidad de La Frontera, PO Box 54-D, Temuco, Chile. \\ Corresponding author: mcdiez@ufro.cl. \\ ${ }^{2}$ Depto Ciencias Químicas, Universidad de La Frontera. \\ ${ }^{3}$ Dipartimento di Scienze del Suolo, della Pianta e dell'Ambiente. Università di Napoli \\ Federico II. Portici, Italia
}

\section{Efecto de Pentaclorofenol sobre la actividad enzimática de algunas enzimas del suelo en un Andisol Chileno}

\begin{abstract}
Keywords: pentachlorophenol, Andisol, laccase, Mn-peroxidase, phosphatase, dehydrogenase.
\end{abstract}

\begin{abstract}
The activities of laccase, Mn-peroxidase, phosphatase and dehydrogenase were studied in a Chilean Andisol (Temuco Serie) contaminated with pentachlorophenol (PCP). Experiments were conducted on the top of $0-20 \mathrm{~cm}$ soil, adding different concentrations of PCP $\left(0.41,4.1\right.$ and $\left.41 \mathrm{mg} \mathrm{kg}^{-1}\right)$. Enzymatic activities and residual concentrations of PCP were evaluated in soil incubated at $25 \pm 1{ }^{\circ} \mathrm{C}$ for 112 days. Enzyme activities of PCP-treated soil varied according to the PCP concentration added. For instance, an inhibitory effect on Mn-peroxidase activity was not observed during incubation at the three levels of PCP, whereas acid phosphatase activity was only affected by the $0.41 \mathrm{mg}$ $\mathrm{kg}^{-1}$ PCP treatment. By contrast, laccase and dehydrogenase activities were negatively affected by the smallest concentration of PCP. After seven days of incubation, no residual PCP was measured in the soil with 0.41 and $4.1 \mathrm{mg} \mathrm{kg}^{-1}$ PCP. By contrast, with $41 \mathrm{mg}$ $\mathrm{kg}^{-1} \mathrm{PCP}$ the amount of phenol in soil decreased gradually and disappeared only after 42 days of incubation. The overall results indicate that PCP concentrations influence some enzymatic activities.
\end{abstract}

Palabras claves: pentaclorophenol, suelo Andisol, lacasa, manganeso peroxidasa, fosfatasa, dehidrogenasa 


\section{RESUMEN}

Se estudio la actividad lacasa, Mn-peroxidasa, fosfatasa y dehidrogenasa en un suelo Andisolchileno(Serie Temuco) contaminado con pentaclorofenol(PCF). Los experimentos fueron conducidos utilizando el perfil $0-20 \mathrm{~cm}$ del suelo y adicionando diferentes concentraciones de PCF $\left(0,41,4,1\right.$ and $41 \mathrm{mg} \mathrm{kg}^{-1}$ dry soil). La actividad enzimática y la concentración residual de PCF fueron evaluadas en el suelo incubado $\left(25 \pm 1{ }^{\circ} \mathrm{C}\right)$ por 112 días. La actividad enzimática del suelo tratado con PCF varió dependiendo de la concentración de PCF adicionada. Por ejemplo, no se observó un efecto inhibitorio sobre la actividad de Mn-peroxidasa durante el periodo de incubación en los tres niveles de PCF, mientras que la fosfatasa ácida fue solo no afectada por el tratamiento con $0,41 \mathrm{mg}$ $\mathrm{kg}^{-1}$. Por otro lado, la actividad de lacasa y dehidrogenasa fueron negativamente afectadas aún por la menor concentración de PCF. Después de 7 días de incubación, no fue medido PCF residual en el suelo con tratamiento con 0,41 y $4,1 \mathrm{mg} \mathrm{kg}^{-1} \mathrm{de}$ PCP. Sin embargo, con $41 \mathrm{mg} \mathrm{kg}^{-1}$ PCP la cantidad de PCF en el suelo disminuyó y completamente desapareció después de 42 días de incubación. El resultado general indica que la adición de PCF influencia algunas actividades enzimáticas del suelo.

\section{INTRODUCTION}

Chlorinated phenols are common environmental contaminants in industrial processing and they are widely used in activities such as wood preservation, textiles and leather production. They are also used as pesticides in agriculture. Although chlorinated phenols persist in many environments, because of their recalcitrance under aerobic (Diez et al., 2002) or anaerobic (Vidal and Diez, 2005) conditions, biological methods have been utilized in groundwater and soil remediation of chlorophenols (Puhakka and Melin, 1997).

Microbial mineralization probably represents the most important route for the detoxification of organic pollutants in soils (Benoit et al., 1999). Biodegradation rates depend on biological and physicochemical factors, such as the type of microorganism community, soil $\mathrm{pH}$, oxygen, nutrient availability, temperature and water availability (Mannisto et al., 2001). The structure and physicochemical properties of the contaminants also affect the rate at which these compounds can be degraded (Rutgers et al., 1998; Simoni et al., 2001) as well as the process used to obtain the biodegradation (Rutgers et al., 1998; Antizar-Ladislao and Galil, 2003). PCP removal from soil can occur either by abiotic (Bollag et al., 1995, Cea et al., 2005) or enzymatic oxidative processes (Bollag, 1992). Nevertheless, phenolic compounds in soil are mainly transformed by oxidative processes, catalyzed by phenolases and peroxidases produced by natural microflora (Sjoblad and Bollag, 1981).

Soil microorganisms can produce extracellular oxidoreductases such as peroxidases, laccases and tyrosinases. These enzymes are involved in the oxidative coupling processes of chlorophenols (Bollag et al., 1995, Gianfreda and Bollag, 2002). Laccase requires $\mathrm{O}_{2}$, but no coenzymes, and produces free radicals that may undergo: i) further non-enzymatic oxidation, ii) reduction or iii) coupling to other phenolic compounds (Bollag, 1992). Peroxidases catalyze the polymerization of several phenolic substances, but they need hydrogen peroxide to be activated. The products of both enzymatic reactions (laccase and peroxidase) are usually less toxic than the parent components (Gianfreda and Bollag, 1994). 
In natural attenuation processes, biochemical and biological soil activities may change with time and the concentration of the contaminant(s) whose transformation is naturally catalyzed. The variation of some enzymatic activities and mainly of those partially involved in the contaminant transformation will occur.

Volcanic soils in Chile are the most important area $(\sim 60 \%)$ of agricultural land (Matus et al., 2006). These soils present high phosphate retention and accumulate large amounts of organic matter and their main clay component is allophane, which is considered a non-crystalline hydrous aluminosilicate characterized by a short range-ordered nature and $\mathrm{Si}-\mathrm{O}-\mathrm{Al}$ bonds predominance (Mora y Barrow, 1996). These soil characteristics play an important role in the adsorption and biodegradation processes of chlorophenols in the soil environment. The interactions between enzyme activity and PCP degradation have been not studied in Chilean volcanic soils.
Therefore, the aim of this work was to evaluate the long-term effect of different amounts of PCP on the activities of dehydrogenase, acid phosphatase, laccase and Mn-peroxidase in a Chilean Andisol.

\section{MATERIALS AND METHODS}

\section{Site description and soil sampling}

The experiments were conducted in an Andisol soil $(0-20 \mathrm{~cm})$ belonging to the Temuco Series, located in the south of Chile ( $\left.38^{\circ} 42^{\prime} \mathrm{S}, 73^{\circ} 35^{\prime} \mathrm{W}\right)$. The soil was collected in April 2002, sieved ( $2 \mathrm{~mm}$ ) and stored in plastic bags at $4^{\circ} \mathrm{C}$. A subsample was air-dried and chemical properties determined according to Sadzawka (1990). Some chemical properties of the Andisol studied are presented in Table 1. The soil presented high level of organic matter (12\%), $\mathrm{N}\left(55 \mathrm{mg} \mathrm{kg}^{-1}\right)$ and $\mathrm{P}\left(15 \mathrm{mg} \mathrm{kg}^{-1}\right)$ and low $\mathrm{pH}$ (5.7).

Table 1. Chemical characterization of Andisol soil assayed $(0-20 \mathrm{~cm})$. (Mean of three replicates).

Tabla 1. Caracterización química del suelo Andisol utilizado $(0-20 \mathrm{~cm})$. (Promedio de tres repeticiones).

\begin{tabular}{lcc}
\hline Parameter & Mean & Standard deviation \\
\hline Organic Matter (\%) & 12 & \pm 0.12 \\
$\mathrm{pH}_{\mathrm{w}}\left(\mathrm{H}_{2} \mathrm{O}\right)$ & 5.7 & \pm 0.12 \\
Phosphorous $\left(\mathrm{mg} \mathrm{kg}^{-1}\right)$ & 15 & \pm 0.30 \\
Nitrogen $\left(\mathrm{mg} \mathrm{kg}^{-1}\right)$ & 55 & \pm 1.1 \\
Copper $\left(\mathrm{mg} \mathrm{kg}^{-1}\right)$ & 2.6 & \pm 0.043 \\
Manganese $\left(\mathrm{mg} \mathrm{kg}^{-1}\right)$ & 2.7 & \pm 0.054 \\
Sulphur $\left(\mathrm{mg} \mathrm{kg}^{-1}\right)$ & 14 & \pm 0.28 \\
Aluminium Saturation $(\%)$ & 3.6 & \pm 0.11 \\
Cation Exchange Capacity $(\mathrm{cmol}+/ \mathrm{kg})$ & 12.2 & \pm 0.37 \\
Addition Bases $(\mathrm{cmol}+/ \mathrm{kg})$ & 11.7 & \pm 0.23 \\
\hline
\end{tabular}




\section{PCP effect on soil enzymatic activities}

To evaluate the long-term effect of different concentrations of PCP on soil enzymatic activities, one $\mathrm{kg}$ of soil $(60 \%$ of water holding capacity) was put into a plastic recipient $(34 \mathrm{~cm} \times 22 \mathrm{~cm} \times 5 \mathrm{~cm})$ and different amounts of PCP $(0.41 ; 4.1$ and $41 \mathrm{mg} \mathrm{kg}^{-1}$ dry soil dissolved in 100 $\mathrm{mM} \mathrm{KOH}$ ) were added. The samples were mixed and incubated at a controlled temperature $\left(25 \pm 1{ }^{\circ} \mathrm{C}\right)$ for 112 days. Water losses by evaporation were compensated weekly to maintain soil water content. A control treatment was included by adding $1 \mathrm{~mL} \mathrm{KOH} 100 \mathrm{mM}$ instead of PCP. Treatments and control were set up in triplicates. About $5 \mathrm{~g}$ of soil were taken periodically to evaluate the enzymatic activities and the residual concentration of PCP.

\section{Enzymatic activities}

Dehydrogenase activity was determined using the method described by Camiña et al (1998). After addition of $1.5 \mathrm{ml}$ of Tris$\mathrm{HCl}$ buffer and $2 \mathrm{ml}$ of a $0.4 \%$ solution of2-(p-iodophenyl)-3-(p-nitrophenyl)5-Phenyltetrazolium chloride, $1 \mathrm{~g}$ soil sample was incubated in the dark for $1 \mathrm{~h}$ in a shaking water bath at $40 \pm 1^{\circ} \mathrm{C}$, mixed thoroughly with $10 \mathrm{ml}$ of $1: 1$ (v/ v) ethanol/dimethylformamide, and left at room temperature for $10 \mathrm{~min}$ before filtration. Iodonitrotetrazolium (INT) was determined spectrophotometrically in the filtrate by measuring the absorbance at $490 \mathrm{~nm}$ and reading the corresponding iodonitrotetrazolium concentration formation (INTF) from a calibration line constructed using samples treated as above, except for the addition of various concentrations of INTF instead of INT. Results are expressed in $\mu$ mol INTF $\mathrm{g}^{-1} \mathrm{~h}^{-1}$ and correspond to the mean of the three values. Acid phosphatase activity was determined with p-nitrophenyl phosphate $(0.18 \mathrm{M})$ as substrate at $\mathrm{pH} 5.5$ (Modified Universal Buffer). After $1 \mathrm{~h}$ incubation at $20 \pm 1^{\circ} \mathrm{C}, 0.5 \mathrm{M} \mathrm{CaCl}_{2}$ was added, and the p-nitrophenol (PNP) released was extracted with $0.5 \mathrm{M} \mathrm{NaOH}$ and measured spectrophotometrically at $400 \mathrm{~nm}$ (Rubio et al., 1990). Phosphatase activity was quantified by reference to a calibration curve constructed using PNP standard concentrations incubated with soil under the same conditions described above, and was expressed in $\mu$ mol PNP g-1 $\mathrm{h}^{-1}$. Laccase activity was determined as described by Bourbunnais and Paice (1990) with some modifications (Saavedra, 2002). ABTS $\left(2,2^{\prime}\right.$ - azinobis - 3 - ethyl benzothiozoline6- sulphonate) oxidation was measured at $420 \mathrm{~nm}$. Briefly, the mixture reaction containing $1 \mathrm{~g}$ of soil in $4 \mathrm{~mL}$ sodium acetate buffer $0.1 \mathrm{M}, \mathrm{pH} 5.0$ and ABTS $0.15 \mathrm{mM}$, was incubated at $25 \pm 1^{\circ} \mathrm{C}$ for $1 \mathrm{~h}$. Manganese peroxidase activity was determined as described by Pasczynski et al. (1988). The mixture reaction contained 1 g soil in sodium tartrate buffer $0.1 \mathrm{M} \mathrm{pH}$ 5.0, $\mathrm{H}_{2} \mathrm{O}_{2} 0.1 \mathrm{mM}$ and $0.1 \mathrm{mM} \mathrm{MnSO}_{4}$. The oxidation of the Mn (II) to Mn (III) was measured at $238 \mathrm{~nm}$ after $30 \mathrm{~min}$ incubation at $25 \pm 1^{\circ} \mathrm{C}$.

\section{Analysis of PCP}

The pentachlorophenol(PCP) concentration in the soil (usually $4 \mathrm{~g}$ ) was determined by High-Performance Liquid Chromatography (HPLC) after extraction with hexane in a soxhlet system as described by SotoCórdoba et al. (2001). HPLC analyses were performed with a Merck Hitachi L7100 pump, a Rheodyne 7725 injector with $20 \mu \mathrm{L}$ loop diode array detector. The detection was set up at $215 \mathrm{~nm}$ and the column was a reverse phase (Lichrosphere 60RP select $\mathrm{B}, 5 \mu \mathrm{m})$. The mobile phase consisted of acetonitrile/phosphoric acid 
$(1: 1 \mathrm{v} / \mathrm{v})$ delivered at a flow rate of $1 \mathrm{~mL} /$ min, at room temperature (about $22{ }^{\circ} \mathrm{C}$ ). Briefly, $4 \mathrm{~g}$ of soil were extracted with hexane for about 16 hours in a soxhlet extractor system and then evaporated at $65^{\circ} \mathrm{C}$ using a rotavapor under reduced pressure. The sample was re-suspended in $5 \mathrm{ml}$ of methanol HPLC grade and filtered at $0.45 \mu \mathrm{m}$ membrane before injection $(20$ $\mu \mathrm{L})$ in the HPLC equipment.

\section{Statistical Analysis}

All experiments and analyses were done in triplicate. The values reported for enzymatic activities are averages of the three determinations expressed on an oven-dried soil basis $\left(105^{\circ} \mathrm{C}\right)$. Analysis of variance (ANOVA) followed by a Tukey's test at the 0.05 level was used when comparison between means was required. All statistical were carried out using SPSS version 9.0 software.

Table 2. $\mathrm{PCP}$ concentration $\left(\mathrm{mg} \mathrm{kg}^{-1}\right)$ during the soil incubation period at $25^{\circ} \mathrm{C}$ (Mean of three replicates)

Tabla 2. Concentración de PCF $\left(\mathrm{mg} \mathrm{kg}^{-1}\right)$ durante el periodo de incubación del suelo a $25{ }^{\circ} \mathrm{C}$ (Promedio de tres repeticiones)

\begin{tabular}{ccccc}
\hline $\begin{array}{c}\text { Incubation Time } \\
\text { (days) }\end{array}$ & \multicolumn{5}{c}{$\begin{array}{c}\text { PCP } \\
\left(\mathbf{m g ~ k g}^{-1}\right)\end{array}$} & \\
\hline 0 & 0.0 & 0.41 & 4.1 & 41 \\
1 & ND & 0.23 & 2.6 & 26.6 \\
7 & ND & 0.028 & 0.4 & 22.4 \\
14 & ND & ND & ND & 7.4 \\
21 & ND & ND & ND & 6.8 \\
35 & ND & ND & ND & 5.8 \\
42 & ND & ND & ND & ND \\
\hline
\end{tabular}

\section{RESULTS AND DISCUSSION}

\section{Fate of the PCP in the soil}

In order to evaluate the transformation of PCP in the soil, it was monitored by HPLC during incubation. This assay was carried out in parallel to the soil enzymatic activities determinations under similar environmental conditions. Table 2 shows residual $\mathrm{PCP}$ in the soil treated with different concentrations of PCP $(0.41 ; 4.1$ and $\left.41 \mathrm{mg} \mathrm{kg}^{-1}\right)$. The PCP concentrations decreased through the incubation, with the treatment with $41 \mathrm{mg} \mathrm{kg}^{-1}$ being the most persistent in the soil and detected until day 35 . In the other two treatments, PCP was detected only until day 7 (Table 2 ). It can be observed that, after one day of incubation, the PCP concentration decreased by almost $50 \%$ at any concentration used. While at the two lower PCP concentrations ( 0.41 and 
4.1 $\mathrm{mg} \mathrm{kg}^{-1}$ ), six more days of incubation were sufficient to further reduce the concentration of the phenol to a residual $10 \%$, at the highest content, 30 more days were required to reach the same residual level.

These results indicate therefore that the PCP removal from the soil was faster in the first hour and then it followed different kinetics depending on the initial PCP concentration added to the soil. This could be explained by different mechanisms occurring during the incubation period.

The great difference between the PCP added to the soil and the PCP founded after 1 day of incubation may be due not only to degradation processes but also to adsorption processes that occur when PCP is added to allophanic soil. Results obtained previously have shown that PCP is strongly adsorbed in this type of soil during the first 24 hours of contact (Cea et al, 2005). Obviously the amount of PCP adsorbed into the soil will be affected not only by the initial PCP concentration value and its characteristics such as the dissociation constant (pKa), but also by soil characteristics such as $\mathrm{pH}$, organic matter content, clay types and others. PCP is a weak acid (pKa is 4.7) and exists in two chemical forms in aqueous solutions: a relatively apolar and slightly soluble phenol $\left(\mathrm{PCP}^{\circ}\right)$ and the dissociated form, a highly soluble phenolate( $\left.\mathrm{PCP}^{-}\right)$. As described by Diez et al. (1999), the adsorption of PCP in allophanic soils is enhanced at low pH values (around 4.5). Furthermore, it might be expected that the toxicity of PCP is enhanced when the $\mathrm{pH}$ is lowered.

The slower kinetic steps in the disappearance of PCP from the soil (Table 2) probably were dominated by the intrinsic degradation and/or transformation carried out by endogenous soil microorganisms resulting in the formation also of phenolic degradation products or humic hybrid components. In both the cases, however, these latter components can be considered as a part of the group of molecules which are precursors to the synthesis of humic acid (Ruttimann-Johnson and Lamar, 1997).

\section{Evaluation of PCP on soil enzyme activities}

The dehydrogenase activity was affected mainly at the highest concentration $(41 \mathrm{mg}$ $\mathrm{kg}^{-1}$ ) and the effect decreased with the lower PCP additions. In general, the activity of the enzyme decreased strongly during the first 3 days, then a stationary situation occurred until day 28; thereafter, the enzyme activity increased regularly and at the end of the incubation period it reached a value of 0.8 $\mu$ moles INTF $\mathrm{g}^{-1} \mathrm{~h}^{-1}$ for the control soil, higher than the initial one $(0.5 \mu$ moles INTF $\mathrm{g}^{-1} \mathrm{~h}^{-1}$ ) (Figure 1). $\mathrm{n}$ soil, dehydrogenase activity is very often considered a reliable indicator of the active microbial biomass, this being an intracellular enzymes whose activity depends on the survival of the living microbial cell. The behavior of dehydrogenase activity shown in Figure 1 could be due to the combination of several effects acting on soil microorganisms and arising from the presence of PCP and its degradation and/or transformation products.

The sudden decrease monitored in the first 3 days of incubation period could be reasonably explained by a strong inhibitory and/or killing effect by PCP on active microbial cells. As the residual PCP concentration decreased, simpler degradation products were probably formed or PCP molecules were removed by partial or total immobilization in the soil matrix. In both cases, a less hostile environment for microorganisms resulted and the latter started to be active and reproduced. The increase of activity monitored after $\mu 50$ days of incubation seems to indicate that degradation leading to products easily available as $\mathrm{C}$ sources rather than entrapment phenomena. 


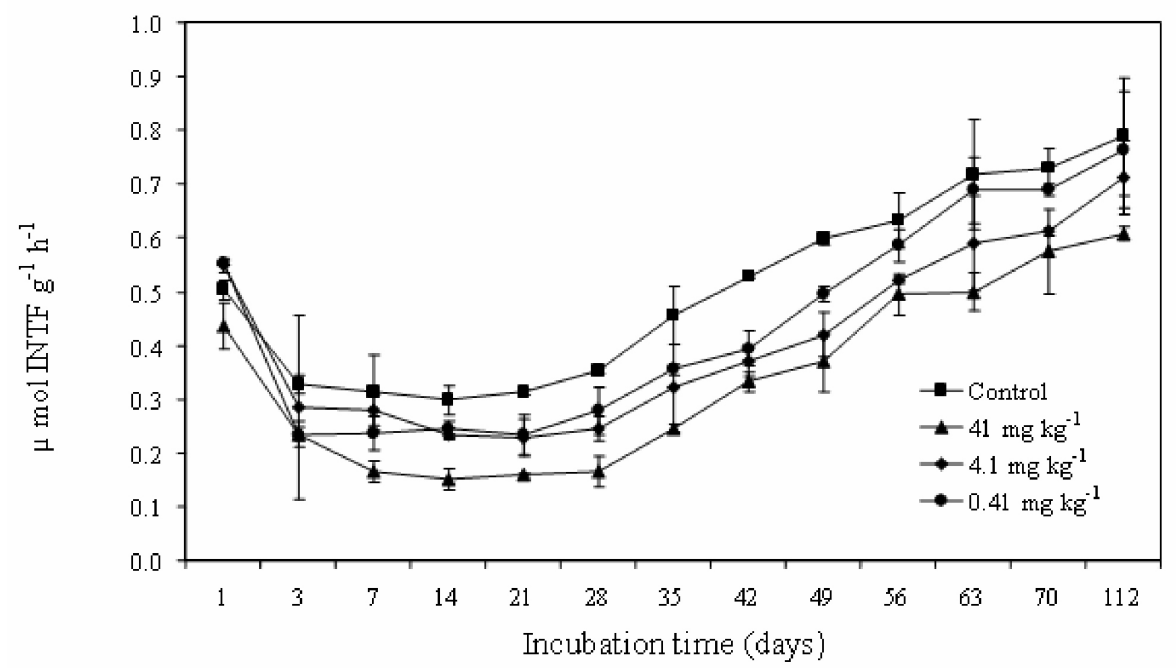

Figure 1. Effect of $\mathrm{PCP}\left(0.41,4.1\right.$ and $\left.41 \mathrm{mg} \mathrm{kg}^{-1}\right)$ on dehydrogenase activity in the soil.

Figura 1. Efecto del PCF $\left(0,41,4,1\right.$ and $\left.41 \mathrm{mg} \mathrm{kg}^{-1}\right)$ sobre la actividad de la dehidrogenasa en el suelo

The inhibition of dehydrogenase activity by PCP was also reported by McGrath and Singleton (2000). In an experiment lasting six weeks and carried out in a sterile soil inoculated with a single fungi species and another soil inoculated with a combination of species, dehydrogenase activity decrease considerably in the soils contaminated by PCP, with its initial concentration being (250 $\mathrm{mg} \mathrm{kg}^{-1}$ ); however, higher concentrations than that were used in this study.

Soil organic matter content also influences the dehydrogenase activity. Martínez Cruz et al. (2002) demonstrated that when the organic matter content diminishes, the response of the dehydrogenase activity is higher since the immobilization of the enzymes on the humic materials often cause an inhibitory effect on their activity (Sarkar et al., 1989). Soil from our study presented an organic matter content of $12 \%$ (Table 1), then also contributed to the initial reduction of deshydrogenase activity. Soil $\mathrm{pH}$ is also an important factor in the activity of this enzyme. In $\mathrm{pH}$ above 6.0 , the enzymatic activity is higher than in more acidic conditions such as in an Andisol soil (Table 1). This may suggest that the soil microflora are subjected to some stress associated with changes in their growing conditions. In the presence of high contaminant concentrations (41 $\left.\mathrm{mg} \mathrm{kg}^{-1}\right)$, these effects were probably much more marked and an adaptation period was needed to allow normal growth of the microbial biomass. This hypothesis seems to be supported by the amounts of proteins measured in the control. A constant protein concentration was measured within 0-60 days (0.01 $\mathrm{mg} \mathrm{g}^{-1}$ in average); thereafter, it increased twofold until the end of the experiment (data not shown).

PCP concentration did not affect Mnperoxidase activity through the incubation showing no significant effect on any treatment (Figure 2). In general, Mnperoxidase activity strongly decreased in the first 3 days, after which time the Mnperoxidase activity increased gradually until day 15 , reaching the highest activity, 
about 730 nmoles $\mathrm{Mn}^{+3} \mathrm{~g}^{-1} \mathrm{~min}^{-1}$, in the treatment with low PCP concentrations. Between 16 and 40 days, the Mn-peroxidase activity decreased slowly for different PCP concentrations and control. After this period, Mn-peroxidase remained almost constant and was similar to the initial one.

The behavior of Mn-peroxidase was quite similar to that of the dehydrogenase shown in Figure 1, at least during the first 3 days, thus supporting an inhibitory effect by PCP, though not dependent on its initial concentration. In contrast to the increase measured with dehydrogenase activity, the stationary value reached by Mn-peroxidase activity could be explained by considering the extracellular nature of this enzyme and the possibility of its stabilization by interaction with organic and inorganic soil colloids.

Diverse studies have demonstrated that PCP concentrations decrease in soils treated with white-rot fungi that produce ligninolitic enzymes (laccase, Mn-peroxidase). These enzymes have a wide range of specificity and it is of a great importance in the transformation and mineralization of organic contaminants with similar structure to lignin (Pointing, 2001). Indeed, their activity has been often correlated with the degradation of PCP inoculated with white-rot fungi.

Initial laccase activity ( measured after 1 day of incubation ) was highest

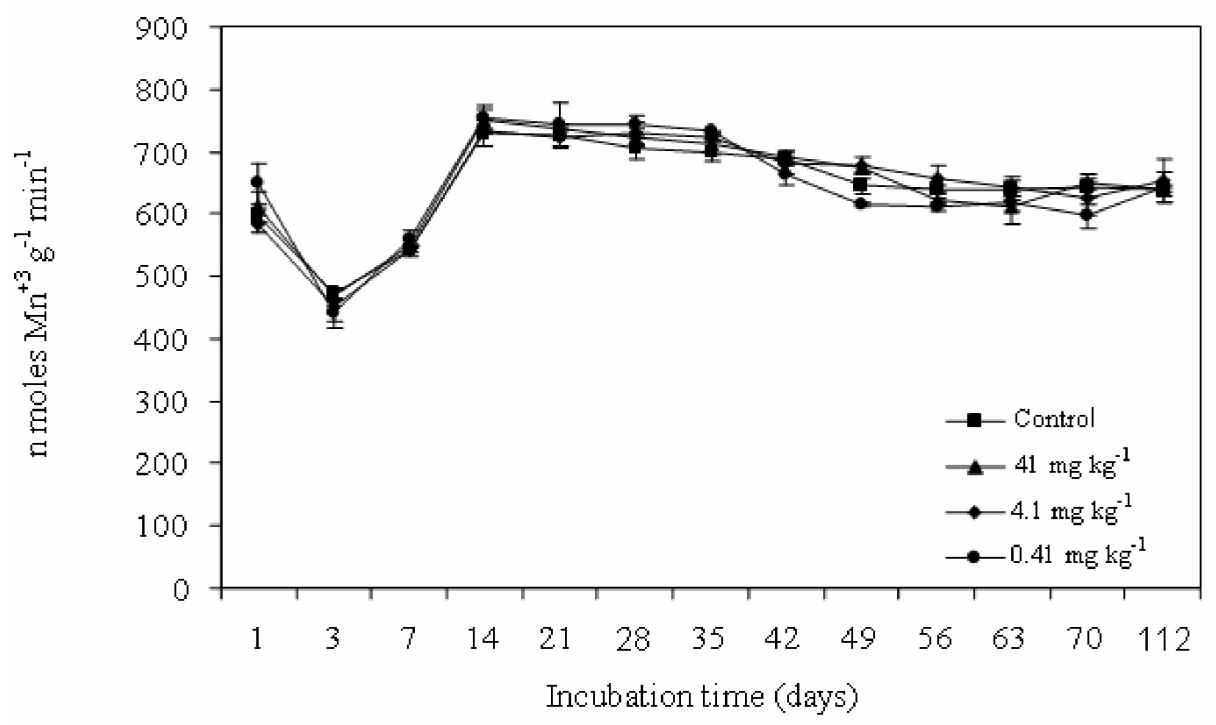

Figure 2. Effect of $\mathrm{PCP}\left(0.41,4.1\right.$ and $\left.41 \mathrm{mg} \mathrm{kg}^{-1}\right)$ on Mn-peroxidase activity in the soil.

Figure 2. Efecto del PCF $\left(0,41,4,1\right.$ and $\left.41 \mathrm{mg} \mathrm{kg}^{-1}\right)$ sobre la actividad de la Mn-peroxidasa en el suelo. 
( $>30 \mu$ moles ABTS g${ }^{-1} \mathrm{~min}^{-1}$ ) in the lowest treatment $\left(0.41 \mathrm{mg} \mathrm{kg}^{-1}\right)$ of PCP addition. However, it decreased with respect to the control treatment when 4.1 and $41 \mathrm{mg}$ $\mathrm{kg}^{-1}$ PCP were added. Laccase activity decreased for all PCP treatments on day 3 of incubation (Figure 3). The initial laccase activity decreased from 20 to 15 $\mu$ moles ABTS $\mathrm{g}^{-1} \mathrm{~min}^{-1}$ after 3 days of incubation in a control treatment with the enzyme activity subsequently becoming stable until the end of the incubation $( \pm 10$ $\mu$ moles ABTS g$\left.{ }^{-1} \mathrm{~min}^{-1}\right)$. On the other hand, for PCP treatments of $0.41,4.1$ and $41 \mathrm{mg}$ $\mathrm{kg}^{-1} \mathrm{PCP}$, the laccase activity decreased progressively reaching the lowest value after 42 day of incubation and from then until the end of incubation a low range of laccase activity was observed showing the persistence of an inhibitory effect.

The initial increase in laccase activity when $0.41 \mathrm{mg} \mathrm{kg}^{-1} \mathrm{PCP}$ was added tallies with data obtained by Saavedra (2002). The author reported that laccase activity was higher than the control sample when $445 \mathrm{mg} \mathrm{kg}^{-1} \mathrm{PCP}$ was added to the soil and the laccase activity evaluated after 1 hour of contact.

Laccase behavior is consistent with that reported by Gianfreda et al. (1998). The authors showed that the higher the phenol concentration, the more pronounced the loss of laccase activity. The authors explained their results as due to the progressive entrapment and/or adsorption of active enzyme molecules within/on phenol polymeric aggregates as they formed.

The activity of acid phosphatase is very important in Andisols from Chile, whose main characteristics are their high $\mathrm{P}$ fixation capacity and their acid $\mathrm{pH}$. Acid phosphatase activity showed an initial increase (day 3) with the addition of the different PCP concentrations, including the control treatment, later phosphatase activity decreased with time. After seven days, acid phosphatase activity remained almost stable up to 56 days of incubation, after which it increased slightly until the end of the incubation period, reaching values similar to the initial ones (Figure 4). The highest $\left(41 \mathrm{mg} \mathrm{kg}^{-1}\right)$ PCP amount

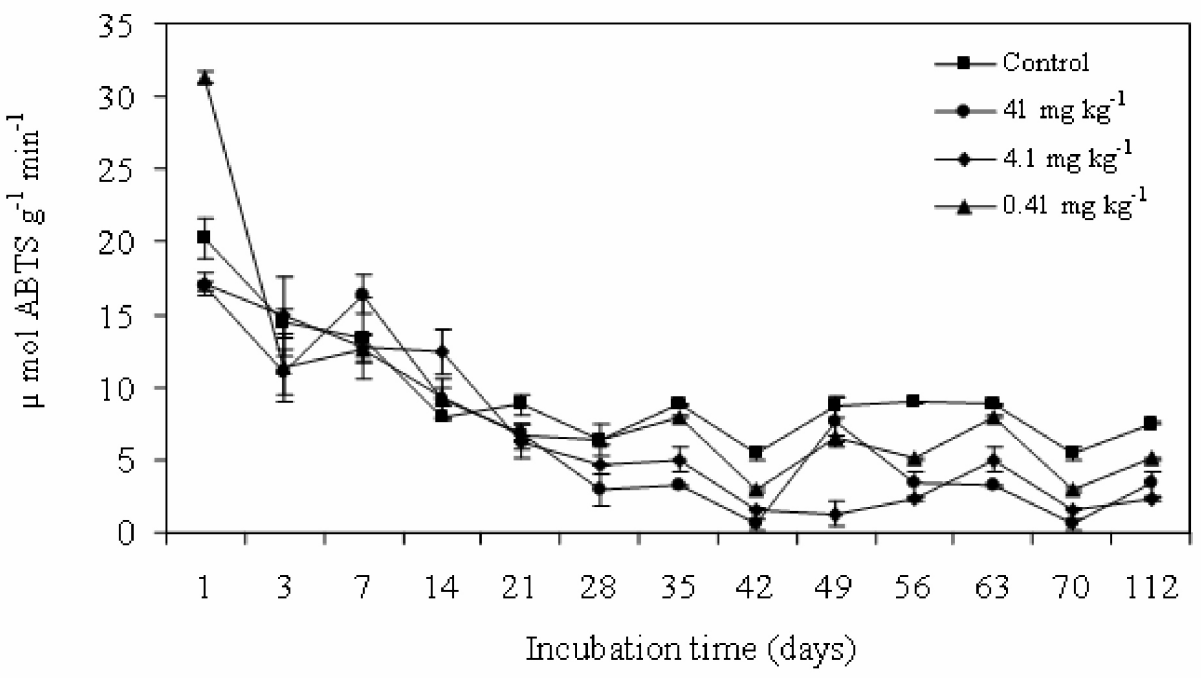

Figure 3. Effect of PCP $\left(0.41,4.1\right.$ and $\left.41 \mathrm{mg} \mathrm{kg}^{-1}\right)$ on laccase activity in the soil.

Figura 3. Efecto del PCF $\left(0,41,4,1\right.$ and $\left.41 \mathrm{mg} \mathrm{kg}^{-1}\right)$ sobre la actividad de la lacasa en el suelo. 


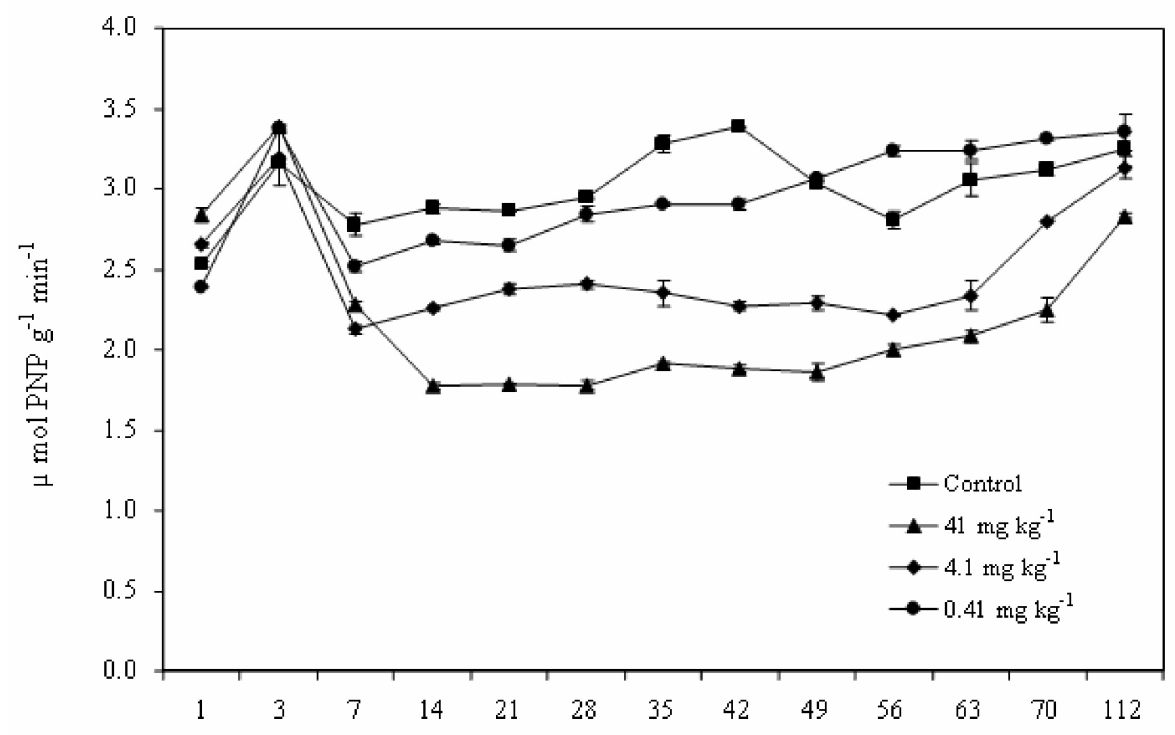

Figure 4. Effect of PCP $\left(0.41,4.1\right.$ and $\left.41 \mathrm{mg} \mathrm{kg}^{-1}\right)$ on phosphatase activity in the soil.

Figura 4. Efecto del PCF $\left(0,41,4,1\right.$ and $\left.41 \mathrm{mg} \mathrm{kg}^{-1}\right)$ sobre la actividad de la fosfatasa en el suelo.

showed the greatest inhibitory effect on phosphatase activity whereas at $0.41 \mathrm{mg} \mathrm{kg}^{-1}$ PCP phosphatase activity was similar to the control soil, showing no inhibitory effect. According to Omar and AbdelSater (2001) at this PCP concentration a stimulative effect on soil microorganism growth may have occurred.

Hydrolases such as phosphatase, hydrolyze numerous substrates into less complex molecules and are considered suitable for the detoxification of xenobiotic substances in the environment. These enzymes have a very broad specificity and do not require cofactors or coenzymes (Gianfreda and Bollag, 1994). As reported by Munnecke et al. (1982), the hydrolysis of pesticides results in a loss of biospecificity and products with both a lower stability and a higher biodegradability are often formed.

\section{CONCLUSIONS}

Pentachlorophenol is one of the most typical examples of xenobiotics that can affect the biological activity of soil. However, PCP removal can spontaneously occur in soil and several factors may participate in this phenomenon, including physical, chemical and biological soil properties. In the long-term experiment performed in this study, the addition of PCP to a Chilean Andisol affected the activities of laccase, dehydrogenase and phosphatase enzymes, mainly at higher concentrations, whereas lower or no effects on acid phosphatase activity were detected at the lowest PCP concentration $\left(0.41 \mathrm{mg} \mathrm{kg}^{-1}\right)$. Mn-peroxidase was not affected by PCP addition, probably due to the characteristics of the allophonic soil used in this study which has high organic matter content and a high PCP adsorption capacity. 


\section{ACKNOWLEDGEMENTS}

The authors would like to thank FONDECYT Project No1010529 and International Cooperation Project CONICYT - CNR No 14662002 for financing. We would also like to thank to Dr. Francisco Matus of the Departamento de Ciencias Químicas, Universidad de La Frontera for his valuable comments and English corrections of the original version of the manuscript.

\section{REFERENCES}

ANTIZAR-LADISLAO, B. AND GALIL, N.I. 2003. Simulation of bioremediation of chlorophenols in a sandy aquifer. Water Research 37, 238-244.

BENOÎT P., BARRIUSO, E., SOULAS, G. 1999. Organic compounds in the environment. degradation of 2,4,-D, 2,4,-dichlorophenol, and 4-chlorophenol in soil after sorption on humified and nonhumified organic matter. Journal Environmental Quality 28, 1127-1135.

BOLLAG, J.-M., MYERS, C., PAL, S., HUANG, P.M. 1995. The role of abiotic and biotic catalysis in the transformation of phenolic compounds. P. 297-308. In P.M. Huang, J. Berthelin, J.-M Bollag, W.B. McGill, A.L.Page (ed) Environmental impacts of soil component interactions. Lewis Publ., Chelsea, M.I.

BOLLAG, J. - M. 1992. Enzymes catalyzing oxidative coupling reactions of pollutants. Met. Ions Biol. Syst. 28, 205-217.

BOURBONNAIS, R., PAICE, M.G. 1990. Oxidation of non-phenolic substrates. An expanded role for laccase in lignin biodegradation. FEBS Letters 267, 99102.

CAMIÑA, F., TRASAR. CEPEDA, C., GIL. SOTRES, F., LEIRÓS, C. 1998. Measurement of dehydrogenase activity in acid soil rich in organic matter. Soil Biology \& Biochemistry 33, 1005-1011.
CEA, M., SEAMAN, J.C., JARA,A., MORA, M.L.AND DIEZ,M.C. 2005. Describing chlorophenol sorption on variablecharge soil using the triple layer model. Journal of Colloid and Interface Science 292,171-178.

M.C DIEZ; S. URETA, G. VIDAL Y M.L. MORA. 1999. The sorption Langmuir isotherms of chlorophenol on allophanic synthetic compounds. $6^{\text {th }}$ International meeting on soils with mediterranean type of climate (IMSMTC). Julio 4-9, Barcelona, España.

DIEZ, M.C., CASTILLO, G., AGUILAR, L., VIDAL, G., AND MORA, M.L. 2002. Operational factors and nutrients effect on activated sludge treatment for phenolic compounds degradation from Pinus radiata kraft mill effluent. Bioresource Technology 83(2), 131-138.

GIANFREDA L., SANNINO, F., FILAZZOLA, M.T., LEONOWICZ, A. 1998. Catalytic behaviour and detoxifying ability of laccase from the fungal strain Cerrena unicolor. Journal of Molecular Catalysis B: Enzymatic 4, 13 - 23.

GIANFREDA, L. and BOLLAG, J. - M., 1994. Effect of soils on behaviour of immobilized enzymes. Soil Science Society of America Journal 58, 16721681.

GIANFREDA, L. AND BOLLAG, J. - M. 2002. Isolated enzymes for the transformation and detoxification of organic pollutants. P 495-538. In R.G. Burns and R. Dick (ed) Enzymes in the environment: Activity, ecology and applications. Marcel Dekker, New York.

MANNISTO, M.K., SALKINOJA-SALONEN, M.S. AND PUHAKKA, J.A. 2001. In situ polycichlorophenol bioremediation potential of the indigenous bacterial community of boreal groundwater. Wat. Res. 35(10): 2496-2504.

MARTÍNEZ - CRUZ A., CARCAÑO MONTIEL, M.G., LÓPEZ - REYES, L. 2002. Actividad biológica en un transepto altitudinal de suelos de la Malinche, Tlaxcala. Terra 20, 141 - 146. 
MATUS, F., AMIGO, X, CHRISTIANSEN, SØREN M. 2006. Aluminium stabilization controls organic carbon levels in Chilean volcanic soils. Geoderma, 132, 158-168

McGRATH R., SINGLETON, I. 2000. Pentachlorophenol transformation in soil : a toxicological assessment. Soil Biology \& Biochemistry 32, 1311 - 1314.

MORA, M.L. AND BARROW, N.J. 1996. The effects of time of incubation on the relation between charge and $\mathrm{pH}$ of soil. European J. of Soil Science 47,131-136.

MUNNECKE, D.M., JOHNSON, L.L., TALBORT, H.W., BARIK, S. 1982. Microbial metabolism and enzymology of selected pesticides. p 1- 32 In: A. M. Chakrabarty (Ed). Biodegradation and detoxification of environmental pollutants. CRC Press, Boca Raton, FL.

OMAR, S.A., ABDEL-SATER, M.A. 2001. Microbial populations and enzyme activities in soil treated whit pesticides. Water, Air, and Pollution 127, 49-63.

PASZCZYNSKI, A., CRAWFORD, R., HUYNH, V. - B. 1988. Manganese peroxidase of Phanerochaete chrysosporium: purification. Methods in Enzymology 161, 264-270.

POINTING, S. (2001). Feasibility of bioremediation by white-rot fungi. Applied Microbiology Biotechnology 57, 20-33.

PUHAKKA, J.A. AND MELIN, ES. 1997. Bioremediation of chlorinated phenols. In: Crawford RL., Crawford DL., editors. Bioremediation: principles and applications. Biotechnology Research Series, Vol. 6. New York. Cambridge University Press.

RUBIO, R., MORAGA, E., BORIE, F. 1990. Acid phosphatase activity and vesiculararbuscular mycorrhizal infection associated with roots of four wheat cultivars. Journal of Plant Nutrition 13, 585-598.
RUTGERS, M., VAN BOMMEL, S., BREURE, A.M., VANANDEL, J.G., DUETZ,W.A. 1998. Effect of $\mathrm{pH}$ on the toxicity and biodegradation of pentachlorophenol by Sphingomonas sp. Strain P5 in Nutristat culture. Enviromental Toxicology and Chemistry 17, 792 .979.

RÜTTIMANN-JOHNSON, C., LAMAR, R.T. 1997. Binding of pentachlorophenol to humic substances in soil by the action of white roots fungi. Soil Biology \& Biochemistry 29, 1143-1148.

SAAVEDRA, G. 2002. Determinación de la lacasa, Mn-peroxidasa, dehidrogenasa y fosfatasa del suelo para evaluar la detoxificación de un suelo Andisol de la IX Region. Tesis de Ingeniería Ambiental. Universidad de La Frontera, Temuco. Chile.

SADZAWKA, A. 1990. Métodos de Análisis de Suelos. Instituto de Investigaciones Agropecuarias. Serie La Platina $N^{\circ} 16$, pp 130. Santiago, Chile.

SARKAR, J.M., LEONOWICSZ, A., BOLLAG, J.M. 1989. Inmobilization of enzymes by clays and soils. Soil Biology \& Biochemistry 21, $223-230$.

SIMONI S.F., SCHAFER, A., HARMS, H. AND ZEHNDER, A.J.B. 2001. Factors affecting mass transfer limited biodegradation in saturated porous media. J. Contam. Hydrol. 50(1-2): 99120.

SJOBLAD, R., AND J.-M. BOLLAG. 1981. Oxidative coupling of aromatic compounds by enzymes from soil microorganisms. In Soil Biochemistry, vol. 5 E.A. Paul and J.N. Ladd (eds). Dekker, New York, pp. 113-152.

SOTO-CÓRDOBA, S.M., BAEZA, J., FREER, J. 2001. Soxhlet extraction of pentachlorophenol from soil with in situ derivatization. Bulletin of the Chilean Society of Chemistry 46,179-185.

VIDAL, G. and DIEZ, M.C. 2005. Methanogenic toxicity and continuous anaerobic treatment of wood processing effluents. Journal of Environmental Management. 74, 317-325. 